\title{
NILAI FATHONAH DALAM PENGELOLAAN BISNIS \\ DI PESANTREN MUKMIN MANDIRI SIDOARJO1)
}

\author{
Fathimatuz Zahroh \\ Mahasiswa Program Studi S1 Ekonomi Islam-Fakultas Ekonomi dan Bisnis-Universitas Airlangga \\ Email : azahrahasan27@gmail.com \\ Muhammad Nafik H.R \\ Departemen Ekonomi Syariah-Fakultas Ekonomi dan Bisnis-Universitas Airlangga \\ Email : muhammadnafik@yahoo.com
}

\begin{abstract}
:
This research is aimed to determine the influence of fathonah value actively rolling in every aspect of business management at Pesantren Mukmin Mandiri Sidoarjo. Pesantren Mukmin Mandiri is one of pesantren based on agrobusiness and agro-industry which graduates entrepreneurs every year.

This research used the qualitative research method and case study as the strategy. Data collection was done by interviewing and observing the research object directly. The qualitative explanatory was used as the technique of analysis by explaining the results of the interviews and of the direct observations.

The results of this research shows that value of fathonah has a good influence in business management at The Pesantren Mukmin Mandiri, it can be seen from the innovation on marketing, production, increased sales, good financial management and proficiency of students in the entrepreneurship.
\end{abstract}

Keywords: fathonah value, intelligence, cleverness, management of businesses, santri, Pesantren Mukmin Mandiri.

\section{Pendahuluan \\ Latar Belakang}

Rezeki ialah sesuatu yang dapat dimanfaatkan manusia, apakah halal atau haram, baik atau buruk. Semua yang tidak dimanfaatkan tetapi tetap dimiliki, rezeki tersebut merupakan milik orang lain. Islam mengajarkan umatnya untuk mendapatkan rezeki dengan cara yang halal dan baik. Rezeki yang halal dan baik bisa diperoleh dengan cara bekerja yang baik, serta tidak meninggalkan kewajiban sebagai seorang muslim.

Jadi, rezeki baik dan tidak baik dalam Islam memang ada. Jalan rezeki baik dan tidak baik disesuaikan dengan cara manusia itu sendiri dalam memperoleh rezeki. Rezeki yang halal akan menarik dan membawa rezeki yang haram akan menimbulkan kemudharatan. Rezeki didapatkan dengan cara bekerja dan berusaha. Salah satunya adalah dengan cara berbisnis.

Berbisnis merupakan salah satu ajaran Islam. Berbisnis yang digolongkan dalam perintah bekerja atau bermuamalah. Dalam Islam, perintah bekerja atau berbuat untuk memperoleh dan menghasilkan manfaat atau nilai tambah ( rezeki ).

Manusia memiliki kecenderungan untuk lebih mengutamakan keuntungan finansial dan mengabaikan etika serta nilai dalam praktik berbisnis, jika hal ini 
diteruskan maka akan terjadi ketidakharmonisan dalam kehidupan. Para pelaku bisnis akan menjadi subjeksubjek yang saling menjatuhkan satu sama lain.

$$
\text { Rasulullah SAW sendiri adalah }
$$
seorang pedagang yang bereputasi internasional dan mendasarkan bangunan bisnisnya kepada nilai-nilai ilahi ( transenden ). Perilaku Rasulullah yang jujur, transparan dan pemurah merupakan kunci keberhasilannya mengelola bisnis Khadijah ra. Dengan dasar itu, beliau membangun system ekonomi Islam yang tercerahkan. Nilai-nilai yang ditawarkan Islam dalam berbisinis juga memiliki beberapa pondasi atau pilar seperti yang dikatakan Syed Nawab Haider Naqvi, dalam bukunya, Etika dan IImu Ekonomi; memaparkan empat aksioma etika ekonomi yaitu : tauhid, keseimbangan ( keadilan ), kebebasan dan tanggung jawab.

Model pebisnis muslim lain yang diterangkan Allah adalah sebagai berikut :



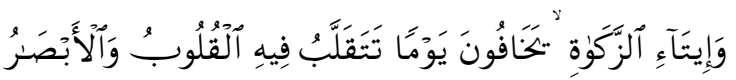

Rijalun la tulhiihim tijaratun wala bayAAun AAan thikri Allahi waiqami alssalati waeetai alzzakati yakhafoona yawman tataqallabu feehi alquloobu waalabsaru

Pebisnis yang tidak dilalaikan oleh perniagaan dan tidak ( pula) oleh jualbeli dari mengingati Allah, dan ( dia) dirikan shalat dan ( dia ) membayarkan zakat. Mereka takut kepada suatu hari yang ( dihari itu) hati dan penglihatan menjadi goncang ( Qs. An-Nur 37 )

Ayat terakhir di atas menjelaskan bahwa dalam berbisnis, berniaga ataupun berjual-beli yang dilakukan oleh seorang muslim jangan sampai melupakan kewajiban sebagai seorang muslim dan lupa dengan Allah, seperti mendirikan shalat dan membayarkan zakat. Hal ini juga bermakna, seorang pebisnis tidak boleh bohong, mengurangi timbangan, tidak boleh berpromosi secara jelek, tidak boleh berperilaku menghalalkan segala cara demi mencapai target kekayaan dunia. Berbisnis yang dikehendaki dalam Islam adalah kegiatan jual beli yang tidak hanya menargetkan keuntungan duniawi saja tapi harus memperhatikan niat awal dan yakni mencari keridhaan Allah SWT dan menolong sesama sebagai bentuk nilai social serta nilai-nilai akhlaqul kharimah yang ada dalam Islam.

Salah satu nilai Islam dalam berbisnis adalah sifat fatonah. Fathonah memiliki arti secara umum adalah cerdas, dimana cerdas adalah salah satu sifat Nabi Muhammad SAW. Rasulullah dalam berdagang menerapkan kecerdasannya untuk mengelola perdagangannya, tidak hanya sampai disitu, beliau juga menjadi pebisnis yang handal karena kecerdasannya dalam menyusun strategi dalam berdagang serta mengatur tata kelola bisnisnya dengan baik.

Sifat fathonah yang diemban nabi Muhammad SAW dalam berdagang tidak 
hanya semata-mata untuk mengambil profit melalui pembangunan strategi dan pengelolaan yang hebat, tapi juga untuk melengkapi hal-hal lain yang berkaitan. Seorang pedagang yang cerdas dipastikan amanah, shiddiq dan tabligh dalam berdagang. Kecerdasan merupakan penyeimbang diantara nilainilai Islam lainnya dalam mengelola bisnis yang wajib dimiliki setiap umat muslim seperti yang telah dicontohkan Rasulullah.

Pondok Pesantren merupakan salah satu tempat yang tepat untuk mengkaji nilai-nilai Islam dalam bisnis. Eksistensi Pondok Pesantren masih tetap mengakar dan menyatu dengan kehidupan masyarakat Islam yang senantiasa diharapkan memberi jawaban alternatif terhadap perubahan dan perkembangan dunia pendidikan. Dewasa ini, dengan kemampuan mendayagunakan potensi sumber daya insani secara maksimal untuk menggali potensi sumber daya alam melalui penyerapan alih teknologi. Hal ini menjadi tantangan dan tuntutan dalam era globalisasi, khususnya bagi Pondok Pesantren yang tengah mengembangkan sayapnya dibidang agro (agrobisnis).

Pesantren Mukmin Mandiri Sidoarjo adalah sebuah Lembaga Pendidikan Pondok Pesantren yang bergerak di bidang agrobisnis dan agroindustri. yang di dirikan oleh Dr. KH. Muhammad Zakki, M.Si, pada tanggal 01 April tahun 2009 dengan Akta Notaris Bambang Santoso, SH, M.Kn. M.Si dan orientasinya mendidik santri berwawasan entrepreneurship dan entrepreneur yang berjiwa santri. yang bertujuan di samping memperluas khazanah keagamaan santri juga memberdayakan dan mengkaryakan ekonomi santri yang terfokus pada aspek agro (agrobisnis), yakni Industri Kopi (Mengolah, memproses kopi biji goreng roaster hingga menjadi kopi bubuk yg sudah beredar dipasar Lokal dan pasar Ekspor dengan Lebel/Merek "Mahkota Raja \& Pendowo Limo" I Mukmin Mandiri.com )

Berdasarkan paparan diatas peneliti tertarik untuk meneliti masalah tersebut karena hasil penilitian ini dibutuhkan banyak elemen, tidak hanya para pebisnis muslim, tetapi juga para santri, siswa bahkan mahasiswa yang berkecimpung di dunia bisnis. Oleh karena itu, penelitian ini berjuduk nilai fathonah dalam pengelolaan bisnis di Pesantren Mukmin Mandiri Sidoarjo. Penelitian ini dilakukan untuk mengetahui nilai fathonah berperan dalam pengelolaan bisnis di pesantren tersebut.

\section{Rumusan Masalah}

Berdasarkan uraian yang telah dikemukakan di atas, maka yang menjadi masalah utama dalam penelitian ini adalah bagaimana nilai fathonah dalam pengelolaan bisnis di Pesantren Mukmin Mandiri Sidoarjo ?

\section{Landasan Teori Konsep Rezeki}

Saleh (2009: 33) Rezeki adalah segala sesuatu yang dapat diambil 
manfaatnya. Makna itu diambil berdasarkan kata "rezeki" yang tercantum dalam terjemahan al-Baqoroh ayat 3. Rezeki dapat berupa vang, makanan, ilmu pengetahuan, rumah, kendaraan, pekerjaan, anak-anak, istri, kesehatan. Ketenangan dan segala sesuatu yang dirasa nikmat dan membawa manfaat bagi manusia. Rezeki merupakan kelengkapan hidup yang pasti Allah SWT. Tidak ada manusia hidup di dunia tanpa dilengkapi rezeki.

Konsep rezeki diterangkan dalam Al-Baqoroh ayat 22 yang berbunyi :

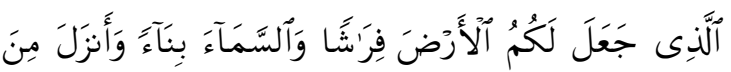

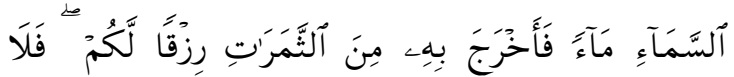



Allathii jaAAala lakumu alarda firashan waalssamaa binaan waanzala mina alssamai maan faakhraja bihi mina alththamarati rizqan lakum fala tajAAaluu lillahi andadan waantum taAAlamuuna Dialah Yang menjadikan bumi sebagai hamparan bagimu dan langit sebagai atap dan Dia menurunkan air ( hujan ) dari langit, lalu Dia menghasilkan dengan hujan itu segala buah-buahan sebagai rezeki untukmu: karena itu janganlah kamu mengadakan sekutu-sekutu bagi Allah padahal kamu mengetahui ( AlBaqoroh $2: 22$ )

Dalam ayat tersebut dijelaskan bahwa Allah menyediakan berbagai macam bentuk rezeki yang diperuntukkan makhluk-Nya. Manusia kadang-kadang mengira bahwa rezeki itu tidak datang semata-mata dari Allah, tapi hanya dari bentuk usaha dan kerja saja. Hal ini yang membuat manusia sesat, musyrik dan mengingkari bahwa rezeki datang dari Allah SWT

\section{Rezeki dan Usaha}

Allah memang telah menyediakan dan memberi manusia rezeki pada porsinya sendiri-sendiri tetapi manusia tidak akan mendapat rezeki tersebut jika tidak berusaha dan bekerja. Usaha manusia tersebut menjadi ukuran sebagai seberapa banyak hasil perolehan. Allah menegaskan dalam Al-Quran bahwa :

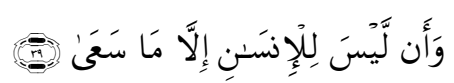

Waan laysa lilinsani illa ma saAAa

Dan bahwasannya seorang manusia tiada memperoleh selain apa yang telah diusahakannya ( An Najm 53: 39 )

Rezeki bisa diperoleh dengan bekerja dan berusaha disamping berdoa dan berikhtiar. Kedua hal tersebut tidak boleh dipisahkan dan akan saling berkaitan. Bekerja dan berusaha tanpa di ikuti doa maka memungkinkan hasil yang diperoleh tidak barokah, atau sebaliknya doa tanpa diiringi bekerja dan berusaha maka cukup mustahil rezeki akan diperoleh. Salah satu bentuk usaha yang diminati masyarakat adalah menjadi pengusaha atau pebisnis. Bisnis dalam Islam tidak akan jauh dari sosok Nabi Muhammad SAW yang dikenal sebagai pebisnis hebat semasa hidupnya.

\section{Bisnis Menurut Prespektif Islam}

Secara umum bisnis diartikan sebagai kegiatan yang dilakukan oleh manusia untuk memperoleh pendapatan 
atau penghasilan dalam rangka memenuhi kebutuhan dan keinginan hidupnya dengan cara mengelola sumber daya ekonomi secara efektik dan efisien. Sedangkan Islam menjelaskan bahwa bisnis adalah serangkaian aktivitas dalam berbagai bentuk yang tidak dibatasi jumlah kepemilikan hartanya ( barang/jasa ) termasuk profitnya, namun dibatasi dalam cara perolehan dan pendayagunaan hartanya ( ada aturan halal dan haram ). Pengertian diatas dapat dijelaskan bahwa Islam mewajibkan setiap muslim, khusunya memiliki tanggungan bekerja. Bekerja merupakan salah satu sebab pokok manusia memiliki harta kekayaan. Allah SWT melapangkan bumi serta meyediakan berbagai fasilitas yang dapat dimanfaatkan untuk mencari rezeki bagi manusia.

Bisnis dalam Islam memiliki posisi yang sangat mulia sekaligus strategis karena bukan sekedar diperbolehkan didalam Islam, melainkan justru diperintahkan oleh Allah Swt di dalam AlQur'an yang artinya

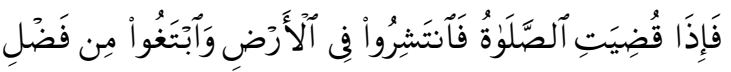

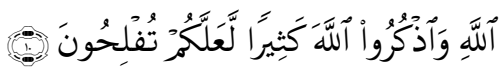

Faitha qudiyati alssalatu faintashiroo fee alardi waibtaghue min fadli Allahi waothkuruu Allaha kathiiran laAAallakum tuflihuuna

Apabila telah diturunkan shalat, maka bertebaranlah kamu di muka bumi; dan carilah karunia Allah ( rezeki) dan ingatlah Allah banyak-banyak supaya kamu beruntung ( Al-Jumuah, 62:10).
Bisnis secara Islam pada dasarnya sama dengan bisnis secara umum, hanya saja harus tunduk dan patuh atas dasar ajaran Al-Quran, As-Sunah, Al-ljma dan Qiyas serta memperhatikan batasanbatasan yang tertuang dalam sumbersumber tersebut.

Dalam ajaran ekonomi Islam semua jenis transaksi dalam bisnis didasar oleh prinsip-prinsip yang menjadi pijakan dan patokan. Prinsip dasar dalam bisnis Islam adalah prinsip ilahiyah ( prinsip ketuhanan ). Semua aktivitas termasuk bisnis yang dilakukan bukan hanya pada dimensi duniawi semata, yang berarti berkaitan untung rugi saja. Lebih dari itu, berbisnis dalam Islam adalah manifestasi dari kehambaan manusia kepada Sang Khalik melalui amal sosial, yakni berbisnis. Berbisnis merupakan aktivitas antar manusia yang saling membutuhkan sedang keuntungannya adalah efek dari saling membantu tersebut. Prinsip ketuhanan ini tidak hanya akan menjadikan bisnis berjalan dengan cara yang benar sesuai aturan syariat, tapi bisnis juga akan lapang dan menyenangkan tanpa rasa takut tersaingin atau tidak mendapat keuntungan yang sama.

Islam memberikan kebebasan kepada pemeluknya untuk melakukan usaha (bisnis) namun dalam Islam ada beberapa prinsip dasar yang menjadi etika normatif yang harus ditaati ketika seorang muslim akan dan sedang menjalankan usaha, diantaranya adalah : 
1. proses mencari rezeki bagi seorang muslim merupakan suatus tugas wajib

2. rezeki yang dicari haruslah rizki yang halal

3. bersikap jujur dalam menjalankan usaha

4. semua proses yang dilakukan dalam rangka mencari rezeki haruslah dijadikan sarana untuk mendekatkan diri kepada Allah SWT.

5. Bisnis yang akan dan sedang dijadikan sebagai sarana berprestasi secara fair dan sehat ( fastabikul al-khayrat )

6. Tidak boleh berpuas diri dengan apa yang sudah didapatkan

7. Menyerahkan setiap amanah kepada ahlinya, bukna kepada sembarang orang sekalipun keluarga sendiri.

Islam meletakkan garis panduan berdagang untuk menjamin keadilan menurut perintah Allah karena hukum bisnis tidak sama dengan pelaksanaan akidah yang memerlukan transformasi secara menyeluruh dan drastis seperti meruntuhkan berhala yang terdapat di Kabah sewaktu pembukaan kota Mekah. Bisnis dibolehkan selama tidak bertentangan dengan syariat.

\section{Landasan Bisnis dalam Islam}

( Anis, 1993:50). Islam menawarkan keterpaduan agama, ekonomi, dan sosial demi membentuk kesatuan. Atas hal inilah para pelaku bisnis dalam melaksanakan pekerjaannya harus menerapkan tiga hal : 1) tidak diskriminasi terhadap pekerja, penjual dan pembeli, mitra kerja atas dasar pertimbangan ras, warna kulit jenis kelamin atau agam, 2) Allah yang paling ditakuti dan dicintai.

Kedua adalah keseimbangan atau keadilan. Sering sekali terjadi pemilahan orientasi seorang pelaku bisnis dengan membedakan antara kehidupan dunia dan akhirat. Kehidupan dunia harus dikejar dengan cara keduniaan, sedangkan kehidupan akhirat diperoleh dengan aktivitas ibadah dalam arti sempit seperti shalat, puasa, zakat dan haji. Padahal Islam sendiri tidak membedakan kehidupan dunia dan akhirat secara terpisah sebab semua aktivitas dapat bernilai ibadah jika bertujuan mencari ridha-Nya yang dilandasi dengan aturanaturan yang telah disyariatkan Allah. Pada dasarnya ajaran Islam berorientasi pada terciptanya karakter manusia yang memiliki sikap dan perilaku yang seimbang dan adil dalam konteks hubungan antara manusia dengan diri sendiri, manusia dengan orang lain ( masyarakat) bahkan manusia dengan Tuhan. Keseimbangan ini ditekankan oleh Allah dalam istilah Ummatan washatan atau yang dikenal sebagai manusia adalah umat yang memiliki kebersamaan, kedinamisan dalam gerak, arah, dan tujuannya serta memiliki aturan-aturan kolektif yang berfungsi sebagai penengah. Oleh karena itu, keseimbangan, 
kemoderatan merupakan prinsip etis mendasar yang harus ditetapkan dalam aktivitas maupun entitas bisnis.

Ketiga adalah kehendak bebas. Berdasarkan konsep kehendak bebas, manusia memiliki kebebasan untuk membuat kontrak dan menepatinya ataupun mengingkarinya. Seorang muslim yang telah menyerahkan hidupnya pada kehendak Allah SWT, akan menepati semua kontrak yang telah dibuatnya, Allah swt memerintahkan kepada kaum muslim untuk memenuhi akad yang telah disepakati.

Keempat adalah pertanggung jawaban. Jika seorang pengusaha muslim berperilaku secara tidak etis, ia tidak dapat meyalahkana tindakannya pada persoalan tekanan bisnis ataupun pada kenyataan bahwa setiap orang juga berperilaku tidak etis. la harus bertanggung jawab atas tindakan yang ia lakukan.

\section{Nilai-Nilai Islam dalam Bisnis}

Rasulullah dalam berdagang memiliki sikap jujur dan adil dalam mengadakan hubungan dagang dengan para pelanggan. Selain itu, dalam berdagang Nabi Muhammad SAW teguh memegang amanah sebagaimana diriwayatkan oleh Abdullah bin Abdul Hamzah, " Aku telah membeli sesuatu dari nabi sebelum ia menerima tugas kenabian. Karena masih ada suatu urusan, aku menjajikan untuk mengantarkan padanya, tetapi aku lupa. Ketika teringat tiga hari kemudian, aku pun pergi ke tempat tersebut dan menemukan nabi masih berada disana. "beliau berkata, "Engkau telah membuat aku resah, aku telah berada disini tiga hari menunggumu " ( H.R Abu Dawud)

Dengan berpegang teguh pada prinsip ini, nabi telah memberi teladan cara terbaik untuk menjadi pedagang yang professional dan ideal bahkan layak diteladani. Cara nabi inilah yang menunjukkan arti kebenaran, kejujuran, dan kemahaan, maka kemakmuran dalam perdagangan akan terwujud ( Afzalurrahman, 2000:26)

\section{Sifat Universal Bisnis Rasulullah}

1. Shiddiq

tidak berdusta dan berkata jujur merupakan arti dari Shiddiq yang harus dilakukan dalam melakukan berbagai macam transaksi bisnis.

2. Fathonah

Fathonah dapat diartikan cerdas, intelektual, kecerdikan atau kebijaksanaan. Pebisnis yang fathonah adalah pebisnis yang mempunyai kemauan berusaha mencari dan menemukan peluang-peluang bisnis yan baru, prospek dan berwawasan masa depan, namun tidak mengabaikan prinsip kekininian.

\section{Amanah}

Amanah berarti dapat dipercaya, kredibel, dan bertanggung jawab, juga bermakna keinginan untuk memenuhi sesuatu sesuai dengan ketentuan, diantara nilai yang terkait dengan 
kejujuran dan melengkapinya adalah amanah.

\section{Tabgligh}

Tabgligh artinya komunikatif dan argumentatif. Istilah ini diterjemahkan dalam bahasa manajemen sebagai supel ( mudah berkomunikasi ), diskripsi tugas, delegasi wewenang, kerja tim, cepat tanggap, koordinasi, kendali dan supervise

\section{Fathonah}

Fathanah artinya mengerti, memahami dan menghayati secara mendalam segala hal yang terjadi dalam tugas dan kewajiban. Sifat ini akan menumbuhkan kreativitas dan inovatif hanya mungkin dimiliki ketika seseorang selalu berusaha untuk menambah berbagai ilmu pengetahuan, peraturan dan informasi baik yang berhubungan dengan pekerjaanya maupun perusahaan umum.

Amri ( $2007: 35$ ) mengatakan bahwa fathanah ( perpaduan antara 'alim dan hafidz ) telah mengantarkan Nabi Yusuf a.s dan timnya berhasil membangun kembali negeri Mesir, sebagaimana terdapat dalam surat Yusuf ayat 55

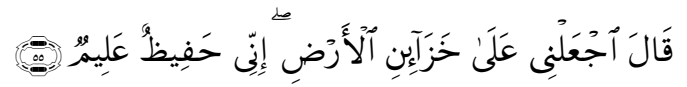

Qala ijAAalnii AAala khazaini alardi innee hafeeun AAaliimun

berkata Yusuf, jadikanlah aku bendaharawan Negara ( Mesir ) sesungguhnya aku adalah orang yang pandai menjaga lagi berpengetahuan

\section{Implementasi Fathonah}

Sifat fathanah dalam penerapan kegiatan bisnis adalah segala sesuatu aktivitas dalam manajemen suatu perusahaan dengan kecerdasan. Pengoptimalan semua potensi yang dimiliki akal yang ada untuk mencapai tujuan. Jika seorang muslim hanya memilki sifat jujur, benar, dan tanggung jawab maka ketiga hal tersebut masih belum cukup dalam mengelola bisnis secara professional. Para pelaku bisnis syariah juga memiliki sebuah kecerdasan ( fathanah ) atau cerdas, cerdik dan bijaksana dengan tujuan agar usahanya bisa lebih efektif dan efisien serta mampu menganalisis situasi persaingan ( complete setting / dan perubahan-perubahan ( changes ) di masa yang akan datang.

\section{Proposisi}

Pesantren yang mengajarkan bisnis kepada para santrinya akan menerapkan nilai fatonah dalam berbisnis.

\section{METODE PENELITIAN}

\section{Pendekatan Penelitian}

Penelitian ini menggunakan pendekatan kualitatif Metode yang digunakan dalam penelitian ini adalah studi kasus. Penggunaan pendekatan deskriptif pada penelitian ini adalah untuk mendeskripsikan hasil temuan yang tidak dapat dikuantitatifkan sehingga perlu diceritakan mendetail. Pendekatan deskriptif pada penelitian ini berguna untuk menceritakan nilai fathonah dalam bisnis di pesantren mukmin mandiri 
Sidoarjo dalam kegitan sehari-hari dan menerapkan kepada para santrinya.

\section{Ruang lingkup Penelitian}

Penelitian ini dilakukan pada Pesantren Mukmin Mandiri Sidoarjo dimana pesantren tersebut menggunakan basis agrobisnis dan agroindustri dalam mendidik santri-santrinya. Ruang lingkup penelitian ini terbatas pada bagaimana nilai fathonah dalam pengelolaan bisnis dan penerapan yang terdapat di pesantren Mukmin Mandiri Sidoarjo.

\section{Jenis dan Sumber Data}

Penilitian ini menggunakan dua jenis data yaitu data primer ( utama) dan data sekunder ( penunjang Data primer diperoleh dengan wawancara langsung yaitu menanyakan sesuati kepada seorang informan. Sedangkan data sekunder dapat diperoleh melalui penelitian sebelumnya yang berupa arsip, laporan-laporan masa lalu, dan dokumen-dokumen yang relevan serta kajian pustaka yang berkaitan dengan permasalahan.

\section{Teknik Keabsahan Data}

Pada tahap ini, peneliti meenghubungi pengasuh pesantren, Pak Muhammad Zakki untuk melakukan janjian wawancara.

Ketika di lokasi atau obyek penelitian

Setelah menyepakati janji yang telah ditentukan, maka peneliti datang ke pesantren yang berada di daerah waru, sidoarjo. Peneliti mengumpulkan data primer yang diperoleh dari observasi dan wawancara dengan pengasuh dan pengurus Pesantren Mukmin Mandiri Sidoarjo yang dilakukan secara terbuka dan berkala. Materi wawancara akan berkembang pada pertemuan berikutnya tetapi tetap terfokus dan mengarah pada topic penelitian sehingga mendapat informasi yang semakin lengkap dan akurat.

Untuk data sekunder, pengumpulan datanya berdasarkan pada kajian pustaka dan literatur mengenai nilai fathonah dalam pengelolaan bisnis, yang diperoleh dengan membaca buku yang sudah dimiliki, membaca buku di ruang baca FEB atau mengakses e-book di internet.

\section{Teknik Analisis Data}

Penelitian ini menggunakan teknik analsisi kualitatif deskriptif. Analisis yang digunakan adalah mencocokan suatu teori dengan kajian proposisi yang telah ditemukan. Tujuan dari pencocokan tersebut adalah menganalisis data studi kasus dengan cara membuat suatu penjelasan ( naratif ), dan menggambarkan (deskripsi) kasus yang bersangkutan dan membuktikan proposisi teoritis yang telah dibuat.

\section{Hasil Analisis dan Pembahasan}

Fathonah memiliki arti kecerdasan, secara lughat pandai atau pintar. Jika dalam istilah adalah pandai menyesuaikan diri kaitannya dalam akan menyampaikan sesuatu. Peranan sifat fathonah juga penting dalam melakukan perencanaan bisnis dan pengelolaannya. Hal ini terkait dengan bagaimana melihat 
peluang dan membuat bisnis semakin naik dan keuangan juga stabil dan sehat.

Nilai fathonah dalam pengelolaan bisnis di Pesantren Mukmin Mandiri diterapkan pada setiap aspek-aspek pengelolaan bisnis. Nilai fathonah merupakan salah satu sifat utama diantara empat sifat baik Rasulullah dalam mengelola bisnis ( amanah, shidiq, tabligh, fathonah / yang diterapkan pesantren Mukmin Mandiri. Hal ini juga bertujuan untuk mencetak santri yang bewawasan wirausaha dan mampu menjadi wirausahawan yang cerdas layaknya Rasulullah.

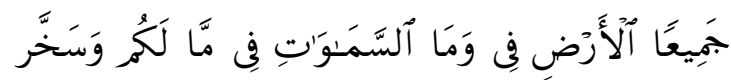



Wasakhkhara lakum ma fii alssamawati wama fee alardi jamiAAan minhu inna fii thalika laayatin liqawmin yatafakkaruna

" Dan Dia menundukkan untukmu apa yang ada di langit dan apa yang ada di bumi semuanya, (sebagai rahmat) daripada-Nya. Sesungguhnya pada yang demikian itu benar-benar terdapat tandatanda (kekuasaan Allah) bagi kaum yang berpikir." ( QS Al- Jatziyah 13)

Al-Quran menjelaskan kecerdasan salah satunya dengan kalimat " bagi kaum yang berfikir ", yang dimaksud dengan kalimat tersebut adalah bahwa kecerdasan itu berada bagi para manusia yang mau menggunakan akalnya untuk bekerja dan berusaha bahkan bertindak dalam kegiatan apapapun. Nilai fathonah hingga penafsiran ayat ini memiliki arti yang luas, dan penerjemahan yang banyak dibeberapa ayat-ayat Al-Quran.
Peneliti melakukan wawancara pada pengurus dan santri pesantren mukmin mandiri sejumlah 3 orang. Para informan ini adalah pengawas langsung dan santri yang terjun sebagai kordinator pemasaran di pengleloaan bisnis kopi Pesantren Mukmin Mandiri.

Dari hasil wawancara yang telah dilakukan menunjukkan bahwa implementasi nilai fathonah dalam pengelolaan bsnis memiliki dampak yang baik di setiap aspek manajemen pengelolaan bisnis kopi di Pesantren Mukmin mandiri Sidoarjo.

Informan 1 menjelaskan nilai fathonah diterapkan pada setiap kegiatan produksi, mulai dari pemilihan biji kopi hingga proses penggorengan dan penggilingan dilakukan oleh santri, hal ini membutuhkan kecerdasan, ketelitian tenaga ahli yang menguasai tentang kopi.

Informan 1 juga menjelaskan kecerdasan dalam memilih target dan segmentasi pasar hingga menentukan strategi pemasaran apa yang sebaiknya digunakan dalam pengelolaan bisnis kopi mahkota raja. Informan 2 mengatakan bahwa dari keseluruhan bentuk pemasaran yang dilakukan para santri kecerdasannya bisa dilihat bagaimana mereka menangkap peluang pasar dan mendapatkan konsumen baru. Informan 3 menjelaskan bahwa implementasi nilai fathonah terlihat dari design kemasan yang marketable, serta kepandaian dalam merawat konsumen, menurut beliau susah bagi seorang pemasar yang 
memiliki latar belakang santri mampu melakukan kegiatan pemasaran yang sedemikian rupa.

Informan 1 mengatakan bahwa implementasi nilai fathonah dalam pengelolaan keuangan terlihat hanya dalam kecakapan mengatur keuangan sehari-hari tetapi juga penerapan system mitra donator yang berguna untuk menghapus sedikit demi sedikit bahwa dalam pemenuhan biaya operasional, pesantren akan meminta sumbangan diberbagai tempat.

Informan 1 menjelaskan pembentukan SDI yang berpegang nilai fathonah dimulai dari penerimaan santri yang diwajibkan training sebelum menjadi santri resmi, selain itu fundamental santri dibentuk melalui penghafalan Al-Quran.

Informan 2 mengatakan bahwa adanya pelatihan condrodimuko ( training awal sebelum masuk pesantren | bertujuan membentuk santri yang tidak hanya cakap dalam ilmu agama tetapi juga siap dalam pengelolaan bisnis kopi.

Kegiatan pengelolaan bisnis di Pesantren Mukmin Mandiri memiliki dampak baik secara langsung maupun tidak langsung. Dampak tersebut juga dapat dilihat selama kegiatan produksi maupun saat evaluasi implementasi nilai fathonah. Dampak tersebut adalah :

1. Penjualan

Sepanjang pertengahan tahun 2014 hingga akhir 2014 penjualan kopi mengalami peningkatan. Nilai fathonah yang diterapkan oleh para santri dalam penjualan dan semangat marketing telah mampu mengantarkan kopi "Mahkota Raja" naik pesat penjualannya. Manajemen marketing dan planning yang diterapkan cukup ampuh untuk meningkatkan penjualan kopi.

\section{Pangsa Pasar}

Informan 2 menjelaskan hingga saat ini para santri mampu berekspansi wilayah distributor, dibuktikan dengan sudah ada beberapa pondok pesantren binaan yang ikut andil dalam penjualan kopi produksi pesantren Mukmin Mandiri selain itu wilayah penjualan yang didongkrak oleh 300 santri tidak tetap juga merupakan salah faktor pendukung ekspansi ini. Hal ini membuktikan bahwa implementasi nilai fathonah dalam pengelolaan bisnis yang ditanamkan kepada para santri memiliki peran besar dalam pengeloaan bisnis kopi mahkota raja.

3. Kemandirian

Mitra donatur adalah donatur yang tidak hanya sekedar menyumbang tetapi juga ikut menikmati hasil produksi kopi para santri Mukmin Mandiri. Seperti yang dijelaskan sebelumnya, metode ini dilakukan untuk menghapus kesan bahwa kemampuan pesantren itu sebatas meminta sumbangan. 
Pesantren Mukmin Mandiri memiliki mitra donatur yang jumlahnya naik turun. Hal ini bukanlah suatu halangan, karena donatur adalah orang yang rela menyumbangkan untuk kepentingan sosial atau sesuatu hal lainnya. Keberhasilan Pesantren Mukmin Mandiri dalam menggaet Mitra Donatur juga merupakan salah satu bentuk implementasi nilai fathonah dalam menjual produk Kopi mereka.

4. Entrepreunur

Implementasi nilai fathonah di Pesantren Mukmin Mandiri yang menyeluruh disegala aspek membuat para santri secara tidak langsung cakap wirausaha. Hal ini dilihat dari kecakapan para santri dalam mengelola bisnis kopi dengan baik, tidak hanya itu mereka juga menerapkan nilai-nilai Islam yang lain. Penerapan nilainilai tersebut merupakan salah satu ciri khas wirausaha Iulusan pesantren dengan yang lain. Para santri tidak hanya paham berwirausaha untuk kepentingan duniawi tetapi juga untuk kepentingan akhirat.

Evaluasi dari dampak implementasi sifat fathonah adalah peningkatan pendapatan penjualan, peningkatan jumlah pelanggan, serta dibuktikannya loyalitas para konsumen lama hingga ekspansi wilayah distribusi diberbagai pondok pesantren bahkan wilayah ekspor. Kepercayaan para mitra donatur juga tetap bertahan dan peningkatan penjualan mulai dari bulan Juli 2014 hingga Desember 2014.

Fathonah tidak hanya memberi efek secara materi kepada perkembangan binis kopi pesantren mukmin mandiri tetapi juga memberikan efek secara spiritual kepada para santri yakni dalam berbisnis tidak hanya teori tentang mendapatkan untung saja, tetapi juga untuk menerapkan nilai-nilai islam dalam perilaku sehari-hari khususnya dalam berbisnis. Informan 1 menjelaskan bahwa jika seorang manusia ingin mendapatkan sukses akhirat, maka orang tersebut wajib menata kehidupan dunianya menuju kesuksesan, karena jika sukses dunia didapat maka akhirat akan mengikuti.

Penjelasan diatas juga berlaku di kegiatan pengelolaan bisnis di Pesantren Mukmin Mandiri. Nilai fathonah yang diterapkan pada setiap kegiatan pengelolaan bisnis didasari atas ilmu pengetahuan yang didapat dari pelatihan-pelatihan dan hasil kajian AlQuran dan hadist-hadist nabi. Para santri menerapkan gaya berbisnis ala Rasulullah yang telah menjadi trendsetter dikalangan pebisnis muslim sejak zaman setelah kepemimpinan Rasulullah.

\section{Keterbatasan Penelitian}

Penilitian ini memiliki beberapa keterbatasan dan jauh dari kata sempurna. Keterbatasan penelitian ini adalah latar belakang pendidikan, serta 
karakter masing-masing informan yang berbeda, sehingga peneliti memiliki ketrbatasan dalam menyampaikan pertanyaan-pertanyaan lebih mendalam. Keterbatasan waktu penelitian yang dilaksanakan pada hari kerja sehingga kurang maksimal dalam wawancara dan tidak mendapatkan informan yang lebih banyak.

\section{DAFTAR PUSTAKA}

Abdussalam, Yusuf. 2009. Bertanya Tuhan tentang Rezeki. Bantul: Media Insani

Afifuddin dan Beni A. Soebani. 2009. Metode Penelitian Kualitatif. Bandung : Pustaka Setia

Afzalurahman. 2000. Muhammad sebagai seorang pedagang

Agustino, Leo. 2008. Dasar-Dasar Kebijakan Publik. Bandung: Alfabeta

Al-Bukhari. 1987. al-Jami' ash-Shahih, Beirut : Dar Ibn Katsir

Arlina, Azti. 2010. Belajar bisnis kepada Khadijah

Amalia, Fitri. Implementasi Etika Bisnis Islam Pada Pedagang di Pasar Madinah Depok, UIN Syarif Hidayatullah. Jakarta Al-Mawardi. 1995. Adab ad-Dunya wa ad-Din. Beirut: Dar al-Fikr,

Efendi, Agus. 2005. Revolusi Kecerdasan Abad 21. Bandung: Alfabet

Elfiky, Ibrahim. 2009. Terapi Berpikir Positif, Terj. Khalifurrahman Fath dan M. Taufik Damas. Jakarta: Zaman

Fauroni, Lukman. 2003. Rekronstuksi Etika Bisnis: Prespektif Al-Quran, sekolah tinggi ilmu syariah Yogyakarta, Volume 4, No.1

Harahap, S. Sofyan. 2011. Etika Bisnis dalam Prespektif Islam. Jakarta: Salemba empat

Hening, Cipta. 2010. Didalam diri ada Allah. Jakarta: PT Elex Media Komputindo

Hidayat, Mohammad. 2010. An Introduction to The Sharia Economic. Jakarta: Zikrul Hakim

Hidayatullah, Haris. Etika Bisnis dalam Prespektif Al-Quran: Upaya membangun bisnis yang Islami untuk menghadapi bisnis di masa depan, Fakultas Agama Islam Unipdu Jombang. Kartikasari, Jeany Megaputri. 2012. Dampak Pengalaman Karakter Amanah Bisnis Nabi Muhmmad SAW pada Kinerja Sosial KJKS BMT-UGT Sidogiri Surabaya. Surabaya: Fakultas Ekonomi dan Bisniss Universitas Airlangga

Kelana, Muslim. 2008. ABCDE Rasul : Muhammad SAW is a Great Enterpreneur. Bandung: Dinar Publisher Kerajaan Arab Saudi. Al-Quran dan terjemahannya. Saudi Arabia

Kotler, Philip. 2004. Dasar-Dasar Pemasaran Jilid I. Jakarta: Prenhallindo. Kotler, Philip. 2008. Dasar-Dasar Pemasaran Jilid II. Jakarta: Prenhallindo Kurniawan, Anggoro Dwi. 2012. Analisis Pengaruh Produk, Promosi, Harga dan Tempat terhadap Keputusan Pembelian. Semarang. Fakultas 
Ekonomika dan Bisnis Universitas Diponegoro

Madjid, Nurcholis dkk. 2002. Ensiklopedi Islam untuk Pelajar. Jakarta: PT. Ichtiar baru van hoeve

Madura, Jeff. 2007. Introduction to Bussiness: Pengantar bisnis edisi 4. Jakarta: Salemba Empat

Malahayati. 2010. Rahasia Sukses Bisnis Rasulullah. Yogyakarta:Jogja great! Publisher

Manullang, M.2006. Dasar-Dasar Manajemen.Jakarta:Ghalia Indonesia Mullins John et.al dan Orville C. Wakler, JR. 2010. Marketing Management: A strategic.Decision-Making Aprroach. Seven Edition. New York: McGraw-Hill Nawatri, Sri.2010. Etika Bisnis Islam Prespektif Islam, Fakultas Ekonomi Universitas Stikubank Semarang, Volume 9, No 1

Orgianus, Yan. 2012. Moralitas Islam dalam Ekonomi \& Bisnis. Bandung: Marja

Pasiak, Taufik. 2008. Revolusi IQ/EQ/SQ Menyingkap Rahasia Kecerdasan Berdasarkan Al-Quran dan Neurosains Mutakhir, Bandung: Mizan Pustaka

Permana, Aji Putra Setya. 2013. Kesesuaian Pengelolaan Bisnis Secara Islam Pada Hotel Syariah I studi kasus pada hotel sofyan Jakarta ). Fakultas Ekonomi dan Bisnis Universitas Airlangga.

Rokan, Mustafa Kamal. 2013. Bisnis ala nabi: teladan Rasulullah Saw dalam bisnis. Yogyakarta: PT. Bentang Pustaka Ryandita, Rr. Anis. 2013. Key success Faktor Pebisnis Muslim Pemilik Parahita
Diagnostic Center Surabaya. Surabaya: Fakultas Eknomi dan Bisnis Universitas Airlangga

Sulaiman, Zakaria dan Aizudinur Zakaria. 2010. Jejak Bisnis Rasullah. Jakarta: PT. Mizan Publika

Sumarni, Murti dan John Soeprihanto. 2005. Pengantar Bisnis ( Dasar-Dasar Ekonomi Perusahaan). Yogyakarta: Liberty Yogyakarta

Saleh, Muwafik. 2009. Bekerja dengan hati Nurani. Jakarta: Penerbit Erlangga

Suprajitno, Aribowo dan Sri Bawono. 2009. Kecerdasan Entrepreneur. Jakarta. PT. Elex Media Komputindo.

Suyanto, M. 2007. Smart in Entrepreneurship: Revolusi Strategis Mengubah Proses Bisnis untuk Meledakan Perusahaan. Yogyakarta: C.V Andi Offset

Syakir, Sula Muhammad dan Hermawan Kertajaya. 2006. Syariah Marketing. Bandung: Pustaka Mizan Sya'rawi, M.Mutawalli. Rezeki Usman, Husaini. 2004. Manajemen: Teori, Praktek, Dan Riset Pendidikan. Jakarta: Bumi Aksara

Yin, Robert K. 2011 . Studi Kasus Desain dan Metode. Jakarta. PT. Raja Grafindo Persada

Yusanto. Menggagas Bisnis Islam www.mukminmandiri.com www.kompasiana.com www.syariahbisnis.com 